Corrections to Metall. Trans. B, 1984, vol. 15B

The Breakdown of Dense Iron Layers on Wustite in $\mathrm{CO} / \mathrm{CO}_{2}$ and $\mathrm{H}_{2} / \mathrm{H}_{2} \mathrm{O}$ Systems

by D. H. St. John, S. P. Matthew, and P. C. Hayes

\title{
Pages 701 to 708:
}

Figure 1(a) $10 \mu \mathrm{m}$ scale bar $7.2 \mathrm{~mm}$ long should be included, i.e., the magnification of the micrograph is $7.2 \times 10^{2}$.

(b) $10 \mu \mathrm{m}$ scale bar $37.8 \mathrm{~mm}$ long should be included, i.e., the magnification of the micrograph is $3.78 \times 10^{3}$.

Figure 2(a) $10 \mu \mathrm{m}$ scale bar $11.1 \mathrm{~mm}$ long should be included, i.e., the magnification of the micrograph is $1.11 \times 10^{3}$.

(b) $10 \mu \mathrm{m}$ scale bar $40.2 \mathrm{~mm}$ long should be included, i.e., the magnification of the micrograph is $4.02 \times 10^{3}$

(c) $1 \mu \mathrm{m}$ scale bar $15.1 \mathrm{~mm}$ long should be included, i.e., the magnification of the micrograph is $1.51 \times 10^{4}$.

Figure 3(a) $10 \mu \mathrm{m}$ scale bar $20.5 \mathrm{~mm}$ long should be included, i.e., the magnification of the micrograph is $2.05 \times 10^{3}$.

(b) $10 \mu \mathrm{m}$ scale bar $49.6 \mathrm{~mm}$ long should be included, i.e., the magnification of the micrograph is $4.96 \times 10^{3}$.

Figure $810 \mu \mathrm{m}$ scale bar $13.3 \mathrm{~mm}$ long should be included, i.e., the magnification of the micrograph is $1.33 \times 10^{3}$.

Establishment of Product Morphology during the Initial Stages of Wustite Reduction

by D. H. St. John, S. P. Matthew, and P. C. Hayes

\section{Pages 709 to 717:}

Figure 10(a) $10 \mu \mathrm{m}$ scale bar $14.4 \mathrm{~mm}$ long should be included, i.e., the magnification of the micrograph is $1.44 \times 10^{3}$.

(b) $10 \mu \mathrm{m}$ scale bar $37.4 \mathrm{~mm}$ long should be included, i.e., the magnification of the micrograph is $3.74 \times 10^{3}$

References 3 through 14 in the script should be all transposed by one so as to correspond to 2 through 13 in references given. Reference 2 given in the script does not exist.

Corrections to Metall. Trans. B, 1985, vol. 16B

Kinetics of the Reaction of $\mathrm{SiO}(\mathrm{g})$ with Carbon Saturated Iron

by B. Ozturk and R. J. Fruehan

Page 121:

Equation [7] should read:

$\mathrm{SiO}_{2}+\mathrm{C}=\mathrm{SiO}+\mathrm{CO}$

\section{Pages 123 and 124:}

In Figures 2 and 5, the labels on the ordinates should read:

AV. $\mathrm{P}_{\mathrm{S} \mathrm{O}} \times 10^{-2}(\mathrm{~Pa})$ and $\mathrm{P}_{\mathrm{S} \mathrm{O}} \times 10^{-2}(\mathrm{~Pa})$, respectively. 